\title{
THE IMPORTANCE OF MOOSE, CARIBOU, DEER, AND SMALL GAME IN THE DIETS OF ALASKANS
}

\author{
KIMBerly Titus ${ }^{1}$, TerRy L. HAYNes ${ }^{2}$ AND Thomas F. PARAGI ${ }^{2}$ \\ ${ }^{1}$ Alaska Department of Fish and Game, Division of Wildlife Conservation, \\ P.O. Box 115526, Juneau, AK 99811, USA. E-mail: kim.titus@alaska.gov \\ ${ }^{2}$ Alaska Department of Fish and Game, Division of Wildlife Conservation, \\ 1300 College Road, Fairbanks, AK 99701, USA.
}

\begin{abstract}
With a statewide human population of about 677,000 (2006-2007 estimate) and at least 84,000 licensed resident hunters, many Alaskans rely on wild game for a significant part of their total diet. Even within Anchorage, the largest city with 283,000 residents, many families consume wild-taken fish (primarily salmon and halibut) and game (Moose, Caribou, deer) even if they did not harvest these resources themselves. We demonstrate through information from hunter harvest reports and subsistence sharing patterns that thousands of Alaskans depend on wild game. For example, some 29,000 hunters kill about 7,300 Moose annually in Alaska. Each harvested Moose and Caribou yields about 256 and $78 \mathrm{~kg}$ of edible meat, respectively. This meat is shared across households. In rural Alaska, reliance on ungulate meat is illustrated by communities such as Nikolai and Akiachak, where about $100 \mathrm{~kg}$ of Moose and Caribou meat are consumed per person annually. Small game, marine mammals, and waterfowl harvested with firearms also contribute to the local diet. The high levels of terrestrial wildlife harvest are allowed under both state and federal subsistence laws that provide a preference for Alaskan residents (under state law) and rural residents (under federal law). Specific regulations authorize long seasons and liberal bag limits for ungulates such as deer (up to six per person per season) and Caribou (five per day) in some areas. Sixty percent of the households in rural Alaska harvest game animals and $86 \%$ of these rural households consume wild game, attesting to the importance of wild foods. Alaskans consider the harvest of wild game as a healthy and cost-effective way to obtain protein as a food source. The extent to which Alaskans who harvest and consume high levels of game meat are at risk to lead exposure from spent ammunition has not been determined. Received 15 September 2008, accepted 17 October 2008.
\end{abstract}

Titus, K., T. L. Haynes, And T. F. PARAgi. 2009. The importance of Moose, Caribou, deer and small game in the diet of Alaskans. In R. T. Watson, M. Fuller, M. Pokras, and W. G. Hunt (Eds.). Ingestion of Lead from Spent Ammunition: Implications for Wildlife and Humans. The Peregrine Fund, Boise, Idaho, USA. DOI 10.4080/ilsa.2009.0312

Key words: Alaska, Alces alces, Caribou, diet, food, hunting, Odocoileus hemionus sitkensis, Rangifer tarandus, Moose, Sitka Black-tailed Deer, wild game.

HARVEST OF WILD FISH AND GAME for human consumption is a widely practiced activity in Alaska. These activities are particularly important in rural areas of Alaska, although even in urban areas there are many families that routinely eat fish and game throughout the year. Depending on the area and time of year in Alaska, harvest of ungulates can be very important to some families and communities. Moose (Alces alces), Caribou (Rangifer tarandus) and Sitka Black-tailed Deer (Odocoileus hemionus 
sitkensis) are the most important big game species harvested. Additionally, in some rural villages, harvest of small game, waterfowl and other birds is locally important, both in the late summer/fall and also during the spring. During the fall and winter months, ungulate harvest can represent all of the red meat protein consumed by many Alaskans.

In addition to harvest for human consumption, harvest of wild game is culturally important to Alaska Natives, including the sharing of Moose, Caribou and deer that is essential for potlatches and other ceremonial events. These harvests are culturally different from those practiced by many non-Alaska Native hunters, although sharing of fish and game resources is common among all Alaskans. Lead ingestion from spent shot in game birds and bullet fragments in big game has been linked to elevated blood lead levels in subsistence hunters in the Canadian Arctic (Tsuji et al. 2008) and may, therefore, be relevant in Alaska also.

Here we review the magnitude of wild game in the diets of Alaskans. We pay particular attention to the laws, regulations and practices that protect this lifestyle. Although the amount of lead from spent ammunition that is ingested by humans while consuming wild game is unknown, we document substantial intake in the amount of game meat consumed annually by Alaskans.

\section{METHODS}

Human Population Trends.-We reviewed human population data available online through the State of Alaska-Department of Labor and Workforce Development (http://www.labor.state.ak.us/home. htm) and the Department of Commerce, Community and Economic Development (http://www. commerce.state.ak.us/dca/commdb/CF_COMDB.htm) where a variety of databases examine the demographic patterns of Alaska's human population.

Hunters and Hunter Harvest Patterns.-We evaluated the location and types of hunters using two primary information sources. First, for rural Alaskans, we used subsistence survey information based on household surveys. These surveys are conducted by subsistence resource specialists from the Alaska Department of Fish and Game (ADFG) who have extensive knowledge of rural Alaska, and have gained the trust of locals to report their subsistence harvests accurately. Second, we evaluated total harvest of Moose, Caribou and deer from mandatory hunter harvest reports and non-mandatory surveys that are conducted annually by ADFG. We chose selected examples of the harvest of Moose, Caribou and deer by community, region, and statewide, where relevant. Both general hunting and subsistence survey results are inexact in Alaska. General hunting surveys are based on Moose and Caribou harvest ticket reports that are mailed in by hunters. Deer harvest is estimated by extrapolation from random hunter surveys based on the harvest tickets they obtain before hunting deer. Subsistence surveys estimate community harvest of fish, game and other wild resources through confidential interviews of households using methods that have been established over the past few decades.

Relevant Laws and Regulations.- - State general and subsistence hunting regulations can be found at www.wildlife.alaska.gov and federal subsistence hunting regulations can be found at http://alaska. fws.gov/asm/index.cfml. Alaska has a few key laws and regulations that are designed to protect and maintain the subsistence way of life. These legal protections can be found in both federal and state laws and regulations. Relevant federal regulations include the Marine Mammal Protection Act (MMPA) and the Alaska National Interests Land Conservation Act (ANILCA). The MMPA provides an exclusive preference for Alaska Natives to harvest marine mammals for food and cultural purposes. For harvest of terrestrial fish and wildlife, ANILCA provides a preference for rural residents to harvest fish and wildlife on federal public lands in Alaska. Urban residents of Anchorage, the Matanuska Valley, Kenai Peninsula, Fairbanks, Ketchikan and Juneau and variously defined surrounding areas, especially along the road system, may be restricted from hunting certain species and are ineligible to federal lands in times of game shortage relative to defined rural needs.

The State of Alaska has strong laws and regulations protecting the harvest and use of fish and wildlife for subsistence purposes. First, the common use clause in the Alaska Constitution (Article 8, Section 3) recognizes that all Alaskans shall have equal ac- 
cess to subsistence resources. The state subsistence law provides a preference for all state residents, and elaborates on methods for choosing among subsistence users when there is not enough fish or game to provide for all uses. The net effect of these federal and state laws is a system whereby Alaska residents have the opportunity to harvest wildlife in numbers unlike most of the USA. In times when big game populations are insufficient to provide reasonable opportunity for harvest by Alaskans, nonresident hunting is closed. Large areas of interior Alaska have had chronically low Moose populations and closed nonresident hunting seasons for several years.

Practical aspects of harvesting wild game in Alaska are also governed by strict regulations associated with the retrieval of game. Wanton waste of game meat is a serious offense, and hunters must bring all of the meat from the field before antlers/horns or other trophies can be retrieved. In addition, in many areas of the state, all of the four quarters and rib cage of harvested Moose and/or Caribou must be salvaged from the field with the "bone-in." These "bone-in" regulations were enacted largely through the insistence of local hunters and are designed to minimize waste of game meat by reducing the surface area of meat exposed to bacteria in the field.

Finally, the State of Alaska has an Intensive Management (IM) law requiring the Alaska Board of Game (BOG; appointed seven person Board that sets wildlife regulations) to identify Moose, Caribou and deer populations that need to be managed to provide sufficient game for high levels of human harvest and consumption. Most deer herds, 11 of 32 Caribou herds, and Moose range covering $40 \%$ of the state have been identified by the BOG as requiring management under the IM law. This law still requires following the sustained yield principle which is set forth in the Alaska Constitution (Article 8 , Section 4). In practice this law has resulted in subsequent regulations that impose management regimes to satisfy the dependence of Alaskans on wild game. The IM law has resulted in management of predators and culling of wolves and/or bears in some instances, with the objective of increasing ungulates for harvest, especially in rural areas. The predator management aspects of the IM law have remained controversial, particularly the culling of wolves (Canis lupus) with the use of aircraft. A full review of this topic, including the science of predator management and human/social issues can be found in the National Research Council (1997) and other reviews such as Decker et al. (2006) and Titus (in press).

Alaska also has some other regulations that protect the importance of the harvest of wild game. For example, there is a proxy hunting regulation allowing a younger hunter to harvest game for an elderly or disabled hunter. There are also federal regulations under ANILCA for designated hunters and a provision in state regulations for community harvest of game. Both are designed to recognize and legalize the fact that a single hunter may harvest multiple big game animals for use by others in her or his community.

\section{RESULTS}

Human Population Patterns. - About $80 \%$ of Alaskans live in urban areas, including 260,000 in the Anchorage area (Division of Subsistence 2000). Generally, these areas are on the main road system (Figure 1). About $20 \%$ of Alaskans live in rural areas, which generally means off the road system (Division of Subsistence 2000). This rural population is split nearly equally between Alaska Natives $(51 \%)$ and those who are not Alaska Native (49\%).

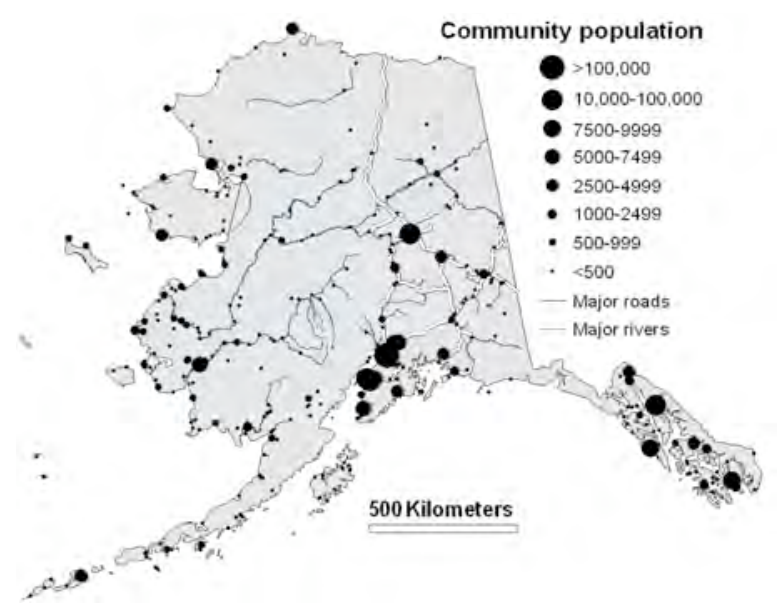

Figure 1. Location of Alaska's cities, towns and villages relative to the road system, major rivers and coastline. 
Many rural communities in Alaska not connected to the road system were established along rivers or in coastal areas because of an historic dependence on marine, aquatic or terrestrial subsistence resources. Some communities have been in existence for thousands of years for this reason, especially in coastal areas where marine resources (fish and marine mammals) were harvested seasonally. Harvest of terrestrial resources, especially Caribou, often resulted in the establishment of communities where migratory Caribou could be depended on seasonally. This is the case for a community like Anaktuvuk Pass in the Brooks Range. Residents of this community seasonally depend on the migration and subsequent harvest of the Western Arctic Caribou Herd as a food resource.

Hunters and Hunter Harvest Patterns.-Alaska averaged about 84,000 resident hunters annually during 1998-2007. This accounts for about $12 \%$ of the residents. These numbers do not reflect the fact that in some rural areas of Alaska, hunting licenses are difficult to obtain and some hunters don't purchase licenses.

Moose are among the most widely distributed species in the state, with a population estimate of $\sim 160,000-200,000$ animals. From 1987-2007, an annual mean of 29,000 Moose hunters harvested 7,260 animals annually. Although they are highly coveted as a trophy species by some, they are far more important as a food resource for thousands of Alaskans (e.g., Boertje et al. 2009). There are a number of Moose herds across the state and densities vary. They are intensively managed for human harvest in some areas, including the harvest of cow Moose (Boertje et al. 2007). Moose hunting regulations are complex and are designed to provide a high sustained yield and the best possible opportunity for local residents. Some areas have winter hunting seasons that are designed to provide food during the winter for local subsistence users. Because of the large size of a Moose (Table 1), many Moose hunters participate in a hunt as a team and the meat is shared among those in the hunting party.

In addition to the general meat salvage requirements for big game, there are very strict salvage requirements in some Game Management Units (GMUs). For example, in GMU 13, the Nelchina Basin,
Table 1. Approximate weight $(\mathrm{kg})$ of Moose, Caribou and deer harvested in Alaska and the respective amounts of boned-out meat.

\begin{tabular}{lccc}
\hline Species & Live & Carcass & $\begin{array}{c}\text { Boned- } \\
\text { out meat }\end{array}$ \\
\hline Moose & 750 & 450 & 255 \\
Caribou & 225 & 136 & 77 \\
Sitka Black-tailed Deer & 90 & 55 & 32 \\
\hline
\end{tabular}

salvage requirements include the heart, liver and all edible meat. In seven GMUs, mostly in interior Alaska, all meat of the front quarters, hindquarters, and ribs must remain naturally attached to the bone until transported from the field or processed for human consumption. For Tier II (State subsistence hunts that are only available for Alaska residents 10 years of age or older) Moose taken in some parts of the state, antler destruction is required to remove any trophy value from the antlers (e.g., typically by cutting across mid-palm on one antler).

Caribou occur in 32 herds in Alaska, and their abundance can vary widely over time. Presently, the Western Arctic Caribou Herd is the largest in the state, in recent years estimated as large as 450,000 animals. When Caribou numbers are high in a herd, hunting has minimal impact on the population, and hunting regulations are often liberal. Annual statewide Caribou harvest is $\sim 27,000$, with nearly $75 \%$ of statewide harvest from the Western Arctic and Teshekpuk herds. Harvest reporting is not required for the large northern herds, so the biologists estimate harvest through hunter contacts and their own experience. Caribou are harvested year-round in some parts of rural, northern Alaska. In GMU 26A (northwest Alaska north of the Brooks Range) there is a resident 365 day bull Caribou season (and cows from 1 July to 15 May) with a bag limit of five per day. Snowmachines and boats are often used for hunting. Like for Moose, in many areas the front quarters, hindquarters and sometimes the ribs of Caribou must be salvaged intact with the meat attached. One State subsistence Caribou hunt requires salvage of the head, hide, heart, liver, kidneys and all edible meat.

Sitka Black-tailed Deer occur naturally in southeast Alaska, and transplanted populations are widely hunted in Prince William Sound and on Kodiak and Afognak islands. In Southeast Alaska, over 11,000 
deer are harvested annually, nearly all by local residents. There is a long season and liberal bag limits in northern Southeast Alaska (GMU 4-Admiralty, Baranof, and Chichagof islands), an area without wolves that serves to allow for higher deer numbers in the absence of a key predator. The state season for all hunters is from 1 August-31 December with a four deer bag limit, and the season for federally qualified subsistence hunters is from 1 August -31 January with a six deer bag limit. Locals annually harvest about 2,400 deer in the Kodiak area and about 2,500 from Prince William Sound. These areas also have long seasons and liberal bag limits. State proxy hunting regulations and federal designated hunter regulations allow for higher harvests in many circumstances.

Small Game Harvest.-Statewide, the numbers of small game (Arctic Hares Lepus arcticus, Snowshoe Hares L. americanus, migratory birds, and resident gallinaceous birds) harvested are unknown. In certain communities and by some individuals, the amount of harvest can be quite high. Across much of Alaska, hare hunting has no closed season and no bag limits. Grouse and ptarmigan hunting regulations vary, but bag limits are often 10,15 or 20 per day with twice that typically as a possession limit. Seasons are typically long (e.g., 10 August31 March).

Community Harvest Patterns.-Surveys of community harvest patterns reveal that many of the 270 rural communities in Alaska harvest significant amounts of wild game. For example, in Nuiqsut on the Arctic coastal plain, about $125 \mathrm{~kg}$ of wild game are harvested annually per capita, and over $80 \%$ of this is represented by Caribou (Table 2). Survey results from 2002 in interior Alaska in Nikolai, showed that $114 \mathrm{~kg}$ of wild game are harvested annually per capita, and about $80 \%$ of this is represented in the harvest of about 38 Moose in that community. In southeast Alaska, where deer are the primary big game species harvested by residents, the Admiralty Island community of Angoon harvests 370 deer annually, representing over $80 \%$ of the annual harvest of $28 \mathrm{~kg}$ of edible meat per capita obtained by hunting. In contrast to communities like Nuiqsut and Nikolai, fish (salmon and halibut) make up a significant amount of the annual per cap- ita portion of the protein diet for many coastal Alaska community residents.

Overall, during the 1990s wild food harvests in Alaska represented $170 \mathrm{~kg}$ per person per year in rural Alaska and $10 \mathrm{~kg}$ per person in urban Alaska (Division of Subsistence 2000). Depending on the region of the state, from $79-92 \%$ of the households in rural Alaska participate in and use game harvested with a firearm as part of their subsistence activities (Division of Subsistence 2000). Since subsistence foods are widely shared, most residents of rural communities make use of wild game, where present. Although these statistics are for rural Alaskans where the consumption is widespread, harvest and use of wild game in the diet of urban Alaskans should not be underestimated in some instances. Even among urban households, Moose, Caribou and deer are widely shared among family and friends. A large bull Moose provides hundreds of kilograms of meat and sharing is likely the norm rather than the exception.

\section{DISCUSSION}

Alaskans harvest significant amounts of wild game annually and in some areas of the state this wild game represents nearly all of the non-fish protein consumed annually in many households. Even in some urban households, Moose, Caribou and/or deer are the primary red meat consumed. A full understanding of the vitamin, contaminant, and potentially the lead levels in the wild game that is harvested is lacking (e.g., Ballew et al. 2006). In some areas of Alaska, the consumption of ungulates is associated with culture, custom and in a few cases, meat salvage requirements. In addition to the frontquarters, hindquarters, ribs, tenderloin, neck and miscellaneous meat, in many cases, the liver, heart, and other animal parts may be consumed. The effect of this consumption on ingestion of lead from spent ammunition is unknown and may be negligible in many cases. In some instances the harvest method may reduce the potential for ingesting spent lead from ammunition. For example, many Caribou are harvested in the autumn along rivers, such as the Kobuk, by shooting the animal in the head using a .22 caliber rifle at close range from a boat pulled alongside the swimming animal, which is a 
Table 2. Selected wild food resources harvested with firearms in rural Alaska communities. ${ }^{a}$

\begin{tabular}{|c|c|c|c|c|c|c|c|c|c|c|c|c|}
\hline Community/Year & 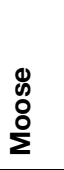 & 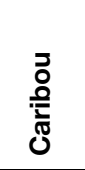 & 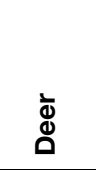 & $\begin{array}{l}\frac{\grave{g}}{0} \\
0 \\
\frac{1}{0} \\
\frac{\pi}{0}\end{array}$ & $\begin{array}{l}\frac{7}{0} \\
\frac{0}{\pi} \\
\frac{0}{2} \\
\frac{0}{2} \\
\frac{1}{0}\end{array}$ & 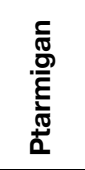 & 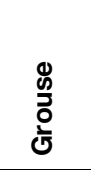 & $\frac{0}{\frac{0}{\pi}}$ & 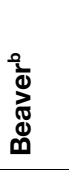 & $\begin{array}{l}\frac{\infty}{\pi \varpi} \\
\Phi\end{array}$ & $\frac{n}{\frac{n}{2}}$ & $\begin{array}{l}\text { Weight (kg) } \\
\text { of edible meat } \\
\text { per capita } \\
\text { obtained } \\
\text { by hunting }\end{array}$ \\
\hline \multicolumn{13}{|l|}{ Akiachak (1998) } \\
\hline No. harvested & 106 & 374 & & 36 & 16,103 & 5,450 & 146 & 2,338 & 433 & 70 & & \\
\hline kg per capita & 66 & 39 & & 5 & 25 & 5 & $<1$ & 5 & 6 & 9 & & 159 \\
\hline \multicolumn{13}{|l|}{ Angoon (1996) } \\
\hline No. harvested & & & 370 & & 144 & & & & & 63 & & \\
\hline kg per capita & & & 23 & & $<1$ & & & & & 4 & & 28 \\
\hline \multicolumn{13}{|l|}{ Barrow (1989) } \\
\hline No. harvested & 40 & 1,656 & & & 12,539 & 329 & & & & 440 & 101 & \\
\hline kg per capita & 3 & 29 & & & 4 & $<1$ & & & & 5 & 11 & 52 \\
\hline \multicolumn{13}{|l|}{ Cordova (1997) } \\
\hline No. harvested & 98 & & 1,441 & 43 & 4,056 & 813 & 1,017 & 2,443 & 145 & 212 & & \\
\hline kg per capita & 10 & & 11 & $<1$ & $<1$ & $<1$ & $<1$ & $<1$ & $<1$ & 1 & & 24 \\
\hline \multicolumn{13}{|l|}{ Kodiak (1993) } \\
\hline No. harvested & 57 & & 2,165 & & 4,140 & & & 1,785 & & & & \\
\hline kg per capita & 2 & & 7 & & $<1$ & & & $<1$ & & & & 10 \\
\hline \multicolumn{13}{|l|}{ Nikolai (2002) } \\
\hline No. harvested & 38 & 17 & & 18 & 395 & 51 & 363 & & 81 & & & \\
\hline kg per capita & 90 & 11 & & 5 & 3 & $<1$ & 1 & & 3 & & & 114 \\
\hline \multicolumn{13}{|l|}{ Nuiqsut (1993) } \\
\hline No. harvested & 9 & 672 & & & 2,238 & 973 & & & & 109 & & \\
\hline kg per capita & 6 & 103 & & & 5 & 1 & & & & 11 & & 125 \\
\hline \multicolumn{13}{|l|}{ Shungnak (2002) } \\
\hline No. harvested & 11 & 403 & & 2 & 1,001 & 264 & & 32 & 52 & & & \\
\hline kg per capita & 11 & 100 & & $<1$ & 5 & $<1$ & & $<1$ & 2 & & & 119 \\
\hline
\end{tabular}

aSource: Alaska Department of Fish and Game, Division of Subsistence, Community Subsistence Information System [http://www.subsistence.adfg.state.ak.us/]

${ }^{\mathrm{b} B e a v e r}$ can be harvested legally with steel traps, snares, and firearms. Legal harvest methods vary by season and from region to region.

${ }^{c}$ Actual amounts may be higher, as not all wildlife species hunted with firearms are included in this table.

legal method in parts of Alaska. Marine mammals, especially seals, are harvested by shooting them in the head, and this part of the animal is not consumed. In other instances, the harvest of Moose results in hundreds of $\mathrm{kg}$ of meat, and large portions of the animal are far away from the location of the bullet wound so that only a small proportion of the meat could be contaminated with lead residue.

Virtually all of the big game harvested in Alaska is with the use of lead ammunition. Copper bullet ammunition is seldom used. Popular rifle calibers for Moose, Caribou and deer include .30-06, .338, .375 , and .300 magnum. In some cases, such as among many deer hunters, rifle and bullet size are larger than generally advised for the big game species. This is because many deer hunters are hunting in the presence of Brown Bears (Ursus arctos) in coastal areas where bear densities are high. As a result, hunters often shoot deer with large loads, and poor shot placement may result in highly damaged meat and many bone fragments. Whether this results in greater dispersal of lead fragments and higher lead ingestion would depend on the location of the shot (e.g., neck, shoulder, ribs), how much damaged meat is discarded, and perhaps the type of "bone-in" and salvage regulation in the hunt area (for Moose and Caribou).

Aside from cultural reasons, the costs of food, fuel (gasoline), and transportation are significant impediments to many rural Alaskans consuming any meat other than wild game. Food is expensive in the 270 bush communities across the state (Division of Subsistence 2000). As of the fall of 2008, gasoline may exceed $\$ 10.00$ per gallon in some bush communities. Many Alaskans dislike beef, chicken, and other processed foods. 
Aside from big game, in many parts of rural Alaska, the harvest of migratory birds can be a significant portion of the diet seasonally (Table 2). Migratory birds are harvested both in the spring and fall. In addition, resident game birds (i.e., grouse and ptarmigan) are harvested in high numbers by some households. Human lead levels associated with the harvest of large numbers of birds is largely unknown, but one might presume that the non-toxic shot now required for waterfowl hunting would reduce lead exposure from this pathway (Johansen et al. 2006, Tsuji et al. 2008). The number of lead shotgun shells still being used in remote villages is unknown, as is the prevalence of lead ammunition to harvest grouse and ptarmigan.

The Alaska Board of Game recently passed regulations restricting the use of lead shot for all bird hunting in GMU 26 (North Slope). In GMU 18 (Yukon-Kuskokwim Delta centered on Bethel), the taking of game under either a hunting or trapping license with lead shot size $\mathrm{T}$ or 0.20 or smaller while in the possession of lead shot, is prohibited. In part, these regulations are designed to reduce the amount of lead shotgun shells in rural villages and force suppliers to provide non-toxic alternatives. These regulations may have the benefit of reducing human exposure to lead via consumption of birds (e.g., Johansen et al. 2001) and other small game, like hares. These regulatory actions, designed initially for bird conservation, may have the broader benefit of helping reduce lead exposure in humans (Rattner et al. 2008).

\section{ACKNOWLEDGMENTS}

We thank the many dedicated staff from the Division of Subsistence, Alaska Department of Fish and Game, who conducted the numerous community harvest surveys over the past few decades. Combined with hunter harvest surveys, these provide the basis for understanding the importance and consumption of wild game to Alaskans.

\section{Literature Cited}

BALlew, C., A. R. TzilKowski, K. HAMrick, AND E. D. NOBMANN. 2006. The contribution of subsistence foods to the total diet of Alaska Natives in 13 rural communities. Ecology of Food and
Nutrition 45:1-26.

Boertje, R. D., K. A. Kellie, C. T. Seaton, M. A. KeECh, D. D. Young, B. W. Dale, L. G. ADAMS, AND A. R. ALDERMAN. 2007. Ranking Alaska Moose nutrition: Signals to begin liberal antlerless harvests. Journal of Wildlife Management 71:1494-1506.

Boertje, R. D., M. A. Keech, D. D. Young, K. A. Kellie, and C. T. Seaton. 2009. Managing for elevated yield of Alaska Moose. Journal of Wildlife Management 73. In press.

DECKER, D. J., C. A. JACOBSON, AND T. L. BROWN. 2006. Situation-specific "impact dependency" as a determinant of management acceptability: insights from wolf and Grizzly Bear management in Alaska. Wildlife Society Bulletin 34:426-432.

DIVISION OF SUBSISTENCE. 2000. Subsistence in Alaska: A year 2000 update. [Online.] Available at www.subsistence. adfg.state.ak.us/download/ subupd00.pdf. Division of Subsistence, Alaska Department of Fish and Game. Juneau, Alaska, USA.

JohANSEN, P., G. ASMUND, AND F. Riget. 2001. Lead contamination of seabirds harvested with lead shot-implications to human diet in Greenland. Environmental Pollution 112:501-504.

Johansen, P., H. S. Pedersen, G. Asmund, AND F. RigET. 2006. Lead shot from hunting as a source of lead in human blood. Environmental Pollution 142:93-97.

NATIONAL RESEARCH COUNCIL. 1997. Wolves, bears and their prey in Alaska. National Academy Press. Washington, DC, USA.

Rattner, B. A., J. C. Franson, S. R. ShefField, C. I. GODDARD, N. J. LEONARD, D. STAND, AND P. J. WINGATE. 2008 Sources and implications of lead ammunition and fishing tackle on natural resources. Wildlife Society Technical Review. The Wildlife Society, Bethesda, Maryland, USA. TITUS, K. In press. Intensive management of wolves and ungulates in Alaska. Transactions of the North American Wildlife and Natural Resources Conference. Portland, Oregon, USA.

Tsuji, L. J. S., B. C. WAINMAN, I. D. MARTin, J. P. Weber, C. Sutherland, E. N. LiberdA, AND E. NiEBOER. 2008. Elevated blood-lead levels in First Nation people of northern Ontario, Canada: policy implications. Bulletin of Environmental Contamination and Toxicology 80:14-18. 